Article

\title{
Biosorption of Methylene Blue Dye Using Natural Biosorbents Made from Weeds
}

\author{
Francisco Silva ${ }^{1, *(1)}$, Lorena Nascimento ${ }^{2}$, Matheus Brito ${ }^{3}$, Kleber da Silva ${ }^{4}$, \\ Waldomiro Paschoal Jr. ${ }^{2, *(D)}$ and Roberto Fujiyama ${ }^{1, *}$ \\ 1 Postgraduate Program in Natural Resource Engineering, Federal University of Pará, \\ Belém, PA 66075-110, Brazil \\ 2 Programa de Pós-Graduação em Física, Universidade Federal do Pará, Belém, PA 66075-110, Brazil \\ 3 Faculty of Chemistry, Federal University of Pará, Belém, PA 66075-110, Brazil \\ 4 Department of Natural Sciences; University of the State of Pará, Belém, PA 66050-540, Brazil \\ * Correspondence: fxavirlima@gmail.com (F.S.); wpaschoaljr@ufpa.br (W.P.J.); \\ fujiyama.ufpa@gmail.com (R.F.); Tel.: +55-91-98281-1852 (F.S.)
}

Received: 20 May 2019; Accepted: 11 July 2019; Published: 5 August 2019

\begin{abstract}
The purpose of this work is to make use of vegetables that, although widely found in nature, there are few applications. The weeds used here, Cyanthilium cinereum (L.) H. Rob (CCLHR) and Paspalum maritimum (PMT) found in the Amazon region of Belém state of Pará-Brazil, contribute to the problem of water contamination by the removal of the methylene blue dye through the biosorption process, taking advantage of other materials for economic viability and processing. The influences of parameters such as, biosorbent dose, contact time, and initial concentration of dye were examined. The characterizations were realized using SEM to verify the morphology of the material and spectroscopy in the FTIR region. As for the adsorption mechanism, the physical adsorption mechanism prevailed. The time required for the system to reach equilibrium for both biosorbents was from $50 \mathrm{~min}$, following a kinetics described by the pseudo-second order model. The adsorption isotherm data for PMT were better adjusted to the Langmuir model and the biosorption capacity $\left(q_{\max }\right)$ value was $(56.1798 \mathrm{mg} / \mathrm{g})$. CCLHR was better adjusted to the Freundlich model and its maximum biosorption capacity was $76.3359 \mathrm{mg} / \mathrm{g}$. Thus, these weed species are promising for the biosorption of methylene blue dye in effluents.
\end{abstract}

Keywords: biosorption; weed; methylene blue dye; natural biosorbents; adsorption isotherms; adsorption kinetics

\section{Introduction}

The occurrence of weeds in the Amazon Region is considered the most serious biological problem faced by cattle ranchers, as well as their control, one of the highest components of the cost of farms production [1]. It is noteworthy that these plants are undesirable and most of the time they are extracted from nature and discarded or eliminated by chemical processes. Another problem in several countries of the world are the industrial processes that generate significant amounts of effluents containing heavy metals and dyes that affect the quality of water one of the resources the most used by living beings. Water is fundamental to the existence and maintenance of life and for this, it must be present in the environment in appropriate quantity and quality [2].

When colorants are present in aquatic environments, color is generally the first impact to be recognized in an effluent because very small amounts of synthetic dyes in water $(<1$ ppm) are highly visible [3]. This substance causes serious problems of aesthetic nature in receiving water bodies, even when present in small quantities [4]. Dyes, besides affecting the aesthetic value of water bodies, 
interfere with the penetration of sunlight into the aquatic environment and thus retard photosynthesis, inhibit the growth of aquatic biotics and interfere with the solubility of gases in bodies of water [5]. In the case of effluents from the textile industries, the dye concentration generally ranges from 10 to $200 \mathrm{mg} / \mathrm{L}$, thus being quite visible [6].

The techniques most commonly used in wastewater treatment are reverse osmosis, ion exchange, adsorption, precipitation [7], membrane filtration [8,9], photocatalysis [10-12] and flocculation [13]. Among these methods, adsorption is one of the most effective methods $[7,14]$ and most feasible due to its cost-effective and easy handling $[15,16]$. Among the adsorbents most applied stand out the zeolites, polymer-based porous materials [17] and, mainly, the activated carbon, most used due to its high surface area, however its use for dye removal is still very expensive, a fact that limits its wide application in the treatment of textile effluents [18]. This has led many researchers to look for more economic and effective adsorbents as potential substitutes for activated carbon [19], resulting in the interest of adsorbents from biomass to be used as sustainable biosorbents.

It is noteworthy that these plants are undesirable and most of the time they are extracted from nature and discarded or eliminated by chemical processes, which is observed two problematic: one is to give a useful end to vegetal species that in the majority of the times causes disorder to different human activities like agricultural, forestry, animal husbandry, ornamental, nautical, energy production between others [20]. The other is chemical contamination of water which is a worldwide concern, in the case here specified by dyes. Compared with other methods, the removal of dyes from aqueous solutions by the adsorption process proved to be an excellent alternative for effluent treatment, as well as an economical technique [21]. The authors report that the use of biological materials for the removal of dyes from aqueous solutions is commonly referred to as biosorption and has now attracted a great deal of interest in scientific knowledge and in the community as sustainable and ecological materials for the production of alternative sorbents. These materials are called biossorvents [22,23].

Aware of the above problems and the search for solutions for the chemical contamination of water, the objective of this research was to evaluate the biosorption potential of biosorbents produced using weeds as Cyanthilium cinereum (L.) H. Rob (CCLHR) and Paspalum maritimum Trin (PMT), collected in the state of Pará amazon region, aiming at the removal of the methylylene blue dye (MB) from aqueous solutions.

The CCLHR and the PMT were characterized by Scanning Electron Microscopy to investigate their morphologies and by Fourier transform infrared spectroscopy (FTIR) to detect the presence of functional groups present in the material that corroborate for their use in the removal of methylene blue (MB) of aqueous solution. PMT is a native species of tropical America, occurring in Central America and the Caribbean, northern Brazil and the coastal zone, from Northeast to South. In Brazil the highest concentrations occur from Pará to Bahia [24]. The CCLHR also known as Vernonia cinerea belongs to the Asteraceae family. The species is native to tropical Africa, tropical Asia, India, Indochina, tropical South America, West India and the US state of Florida [25].

Recent studies indicate that approximately $12 \%$ of the synthetic dyes are lost during manufacturing and processing operations and that about $20 \%$ end up entering the environment through effluents from industrial wastewater treatment plants [26]. Dyes have a complex chemical structure that is stable to light, heat, oxidizing agents and are also resistant to aerobic digestion $[27,28]$. Methylene blue is a cationic dye widely used in the textile industry for the dyeing of cotton and wool fabrics. When untreated, uncontrolled discharge into rivers and lakes affect not only the transparency of the waters, but also limits the passage of solar radiation, reducing the natural photosynthetic activity and causing changes in the aquatic biota and causing acute and chronic toxicity of these ecosystems $[29,30]$.

As has already been synthetically mentioned, an appropriate alternative method, which has proved to be quite effective for removal of dyes from aquatic environments is biosorption, a subcategory of adsorption, which uses as biological raw material where the lingnocellulosics are included. In this class of materials, agricultural byproducts have been shown to be efficient because, in addition to being abundant, they are inexpensive and have a relatively low impact on the environment. In comparison to 
other effluent treatment methods, biosorption substantially reduces the costs associated with financial investment in the process as a whole [31,32].

Several works that deal with the removal of methylene blue are presented in the literature using biosorbents obtained from lignocellulosic materials in the in natura form such as coconut fiber [33], banana peel [34], mint tailings [35], pineapple peel [36], cashew nutshell [37] pine leaves [38], tea residues [39], corn straw, pupunha palm [40], trunk of the papaya tree [41]. In this paper, the biosorbents presented for the removal of methylene blue dye (MB) were produced from weeds that can be defined as any plants that grow spontaneously in a place of human activity and cause damage to this activity, be it agricultural, forestry, livestock, ornamental, nautical, energy production etc. [42].

This work has objective produce biosorbents through weeds (PMT and CCLHR) and realize biosorptions test to verify removal efficiency MB from aqueous solutions. In the biosorption assays, the influence of parameters such as dosage of biosorbents between $(0.05-0.5 \mathrm{~g})$, initial concentration of dye in the range of $(10.0$ and $50.0 \mathrm{mg} / \mathrm{L})$, and contact time (10 and $80 \mathrm{~min})$ were evaluated. The experimental data of biosorption isotherms were evaluated by the Freundlich and Langmuir models and biosorption kinetics by the pseudo-first-order and pseudo-second-order models. The maximum biosorption capacity $\left(q_{\max }\right)$ values were $56.1798 \mathrm{mg} / \mathrm{g}$ for the PMT, whose experimental biosorption isotherm data were better adjusted with the Langmuir model and $76.3359 \mathrm{mg} / \mathrm{g}$ for the CCLHR, whose experimental data of biosorption isotherms were better fitted to the Freundlich model. Finally, the research result shows the biosorbent's potential for removal MB from waste water. It is expected that this research will contribute as an alternative in the problematic of the water chemical contamination, using a simple reproduction process and a wide availability of raw material for biosorbents production.

\section{Materials and Methods}

\subsection{Preparation of Biosorbent}

The used biosorbent were produced from weeds (Cyanthilium cinereum (L.) H. Rob e Paspalum maritimum Trin). The weeds found in the Amazon region, Belém-PA, Brazil. They were collected manually within the Universidade Federal do Pará (UFPA). After harvesting, the stems were extracted and cut into lengths of approximately $5 \mathrm{~mm}$. The trimmed stems were washed in distilled water and introduced in an oven at $400{ }^{\circ} \mathrm{C}$ for 30 days, to reduce humidity and to avoid attack of microorganisms. After 30 days, the dried samples were again crushed and washed with distilled water until we did not observe more of the coloration in the solution. The wet samples were placed in an oven at $800{ }^{\circ} \mathrm{C}$ for $24 \mathrm{~h}$. The prepared biosorbents from weeds were stored in airtight plastic containers in order to avoid humidity, and these were utilized in the biosorption assays.

\subsection{Solutions and Reagents}

In the present study of biosorption, the used adsorbate was the methylene blue dye (MB), classified as basic or cationic. A stock solution of $100 \mathrm{mg} / \mathrm{L}$ was prepared separately, which was diluted to between 10 and $50 \mathrm{mg} / \mathrm{L}$. The molecular structure and chemical formula of the Cationic dye of methylene blue are shown in Table 1.

Table 1. Dye characteristics.

Cationic Dye Molecular Structure




\subsection{Used Equipments at the Characterization}

In the Fourier Transform Infrared Spectroscopy (FT-IR) of the biosorbents was used Perkin Elmer Spectrum Two, in order to verify functional groups present in the samples. The biosorbents morphological was investigated by using Tescan scanning electron microscope (SEM) (Vega3 SB).

\subsection{Biosorption Experimental Procedure}

The biosorption is biomass ability to adsorb surface pollutants by carboxylic and phenolic functional groups, in which neutral $\mathrm{pH}$ make deprotonated and negative charge removes cations from solution by means of process as complexation, ionic exchange and adsorption [43].

The biosorption studies for the assessment of weeds (Cyanthilium cinereum (L.) H. Rob and Paspalum maritimum Trin) for the removal of $\mathrm{MB}$ dye from aqueous solutions was conducted by means of the batch biosorption procedure using $50 \mathrm{~mL}-\mathrm{pH} 7$ of solution, submitted to constant agitation speed of $150 \mathrm{rpm}$ by magnetic stirrer (QUIMIS-Q221 MAG model), without temperature control. We analyzed the influence of parameters such as biosorbent dosage between $0.05-0.5 \mathrm{~g}$, initial dye concentration in the range of 10.0 and $50.0 \mathrm{mg} / \mathrm{L}$ and contact time between $10-80 \mathrm{~min}$. During each procedure at predetermined time intervals, solution samples were taken for residual analysis of MB concentrations using spectrophotometer. Equations (1) and (2) were used to calculate the percentage of removal and the biosorption capacity, respectively:

$$
\begin{gathered}
R \%=\frac{\left(c_{0}-c\right)}{c_{0}} \times 100 \% \\
q(t)=\frac{\left(c_{0}-c\right)}{m} \times \mathrm{V}
\end{gathered}
$$

where:

$$
\begin{aligned}
& R \%=\text { Percentage of removal } \\
& c_{0}=\text { Initial concentration }(\mathrm{mg} / \mathrm{L}) \\
& c=\text { Concentration at time } \mathrm{t} \\
& V=\text { Volume }(\mathrm{L}) \\
& q(t)=\text { Biosorption capacity at time } \mathrm{t} \\
& m=\text { Biosorbent mass. }
\end{aligned}
$$

\section{Results}

\subsection{Characterization of PMT and CCLHR Biosorbents}

Figure 1 shows the FTIR results for the identification of the present functional groups in the PMT and CCLHR species. In the range of $3000-3720 \mathrm{~cm}^{-1}$, a broad and low intensity band was observed, peaks at $3330 \mathrm{~cm}^{-1}$ (Figure 1a) and $3320 \mathrm{~cm}^{-1}$ (Figure $1 \mathrm{~b}$ ), characterizing the presence of $\mathrm{O}-\mathrm{H}$ (alcohols and phenols) [44]. Peaks were also observed at $1630 \mathrm{~cm}^{-1}$ (Figure 1a) and $1613 \mathrm{~cm}^{-1}$ (Figure 1b), which indicated the $\mathrm{C}=\mathrm{O}$ stretching in organic groups of carboxyl and bending vibration of the functional group -OH [45]. The intense band at $1035 \mathrm{~cm}^{-1}$ (Figure 1a) and $1033 \mathrm{~cm}^{-1}$ (Figure 1b) peaks confirm the functional groups $\mathrm{O}-\mathrm{C}-\mathrm{O}$ of the cellulose and lignin structure.

The biosorption of MB on the adsorbent may be due to the electrostatic attraction between these groups and the cationic dye molecule. At $\mathrm{pH}$ above 4, the carboxylic groups are deprotonated and negatively charged carboxylate ligands (-COO-) bind to the positively charged $\mathrm{MB}$ molecules. This confirms that the biosorption of MB by adsorbent was an ion exchange mechanism between the negatively charged groups present in adsorbent and the cationic dye molecule [46]. 


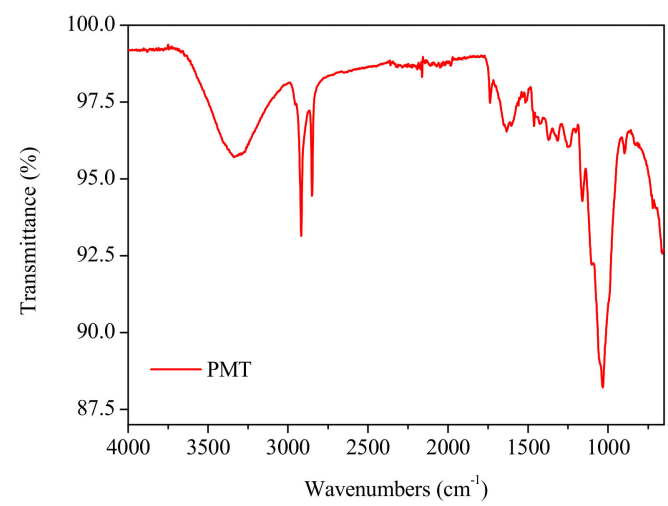

(a)

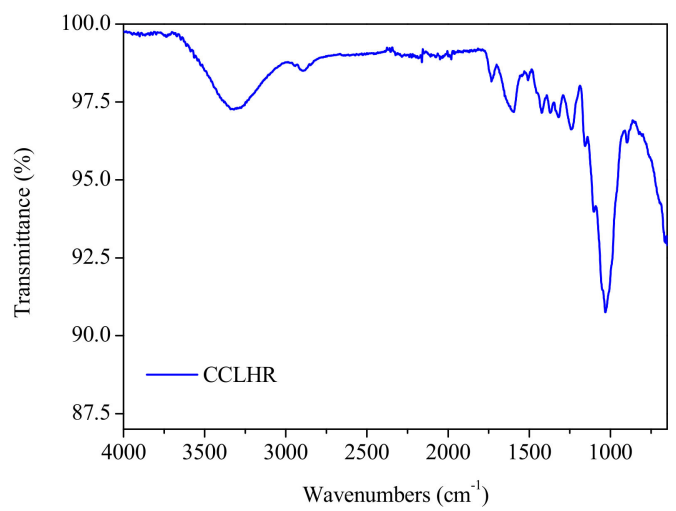

(b)

Figure 1. Infrared spectrum of Paspalum maritimum (PMT) (a) and CCLHR (b) samples, in the range of $400-4000 \mathrm{~cm}^{-1}$.

The Scanning Electron Microscopy images of PTM and CCLHR are shown in Figure 2 with magnification of $2190 \times$ and $1720 \times$, respectively The SEM analyzes showed a large amount of pores implying a wide surface area, which facilitates the MB biosorption process [40]. This indicates a necessary requirement of these lignocellulosic materials as potential biosorbents. In general, the PMT and CCLHR presented different morphologies along their surface demonstrating different pores sizes and heterogeneous surfaces.

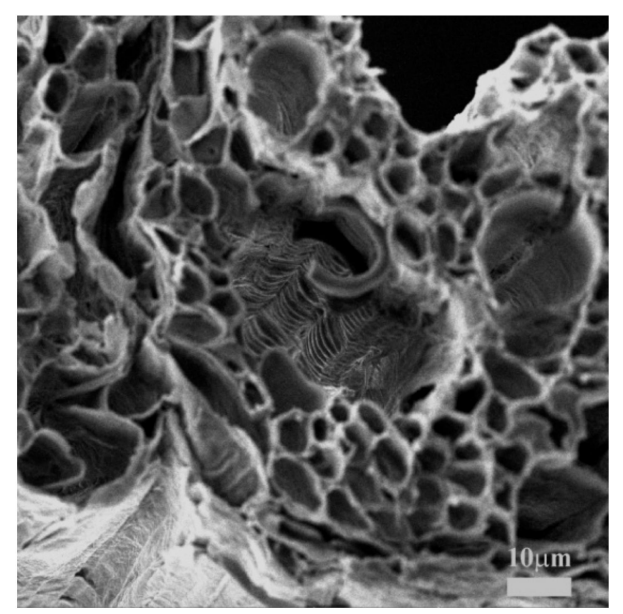

(a)

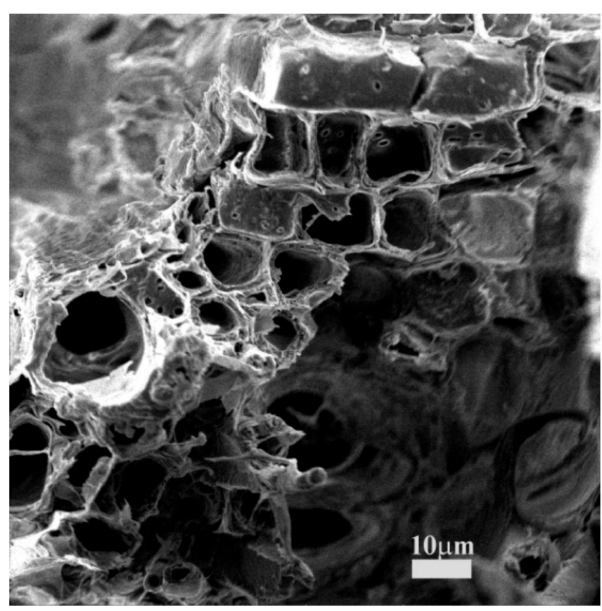

(b)

Figure 2. Scanning electron microscope (SEM) image of (a) PMT with magnification of 2190× and (b) CCLHR with magnification of $1720 \times$.

The characterization results by SEM and FTIR show the predominance the physical adsorption mechanism due to the porosity of the material and the electrostatic interaction between the biosorbent and the methylene blue.

\subsection{The Effect of Dosage}

The biosorption capacity represent the biosorbate mass can be retained by the biosorbent mass while percentage of removal is related to speed which the biosorbate flows from solution to biosorbent surface. The MB biosorption by the CCLHR and PMT plant species was examined by dosage variation of 0.05 to $0.5 \mathrm{~g}$ in the concentration $15 \mathrm{mg} / \mathrm{L}$, solution volume of $50 \mathrm{~mL}$ and agitation speed $150 \mathrm{rpm}$. For both species, we observed that the increase in the mass of produced biosorbents led to an increase at the percentage of removal, with CCLHR from $80.96 \%$ to $98.15 \%$ and PMT from $92.33 \%$ to $95.88 \%$. 
However, increasing the dosage from 0.05 to $0.5 \mathrm{~g}$ caused a decrease in biosorption capacity, where for CCLHR form 12.11 to $1.47 \mathrm{mg} / \mathrm{g}$, whereas for PMT from 13.85 for $1.44 \mathrm{mg} / \mathrm{g}$. The increase in the percentage of removal with increasing dosage is because the larger amount of mass provided a larger number of active sites available for the biosorption, which causes the increase of the percentage of removal as already reported in the literatures $[47,48]$. The decrease of the biosorption capacity with the increase of the biosorbent dosage can be explained by the unsaturation of a certain number of active sites, since the volume and concentration remained fixed to a higher mass value, in which should be distributed the same amount of dye. Also, there is the particle aggregation due to the increase of the biosorbent dosage, which causes a decrease in the surface area and the increase of the diffusion path to be travelled by the adsorbate inside the biosorbent [48-54]. Figure 3 shows the curves of biosorbent dose vs. biosorption capacity and biosorbent dose vs. percentage of removal of PTM and CCLHR.

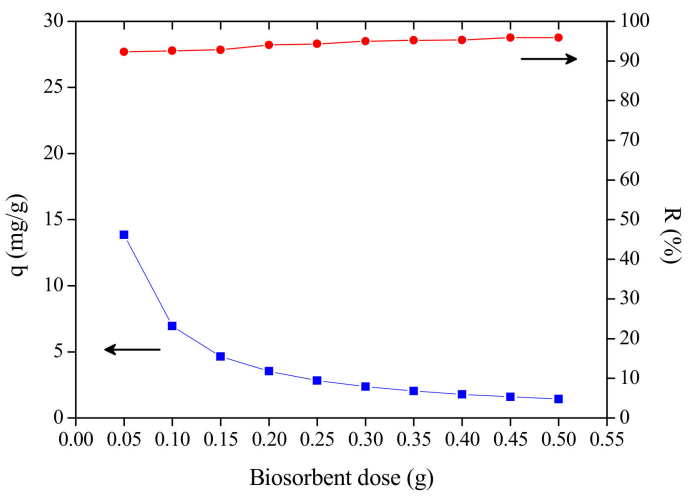

(a)

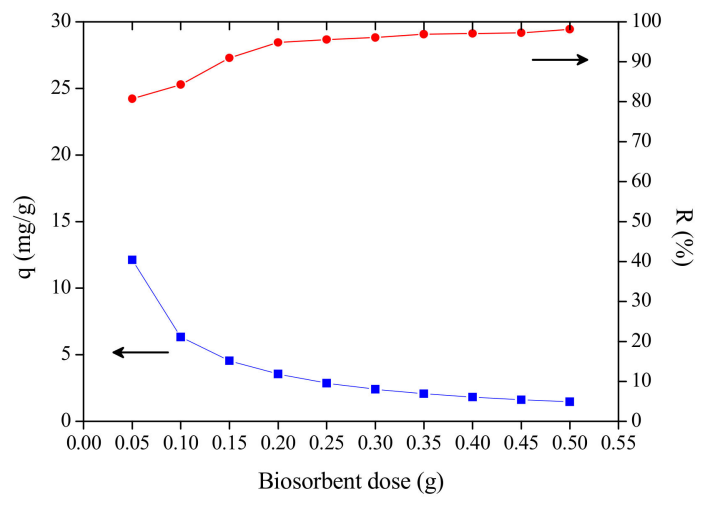

(b)

Figure 3. Biosorbent dose vs. biosorption capacity vs. percentage of removal: (a) PMT and (b) CCLHR.

\subsection{Effect of Initial Dye Concentration}

The initial dye concentration in the range of $10-50 \mathrm{mg} / \mathrm{L}$ was studied for the assessment of $\mathrm{MB}$ biosorption using a biosorbent dosage of $0.05 \mathrm{~g}$. The biosorption capacity increased with increasing concentration from 9.03 to $41.99 \mathrm{mg} / \mathrm{g}$ (MB) for CCLHR biosorbent and from 9.31 to $41.67 \mathrm{mg} / \mathrm{g}$ (MB) for PMT biosorbent. The percentage of removal decreased from $90.36 \%$ to $83.98 \%$ for CCLHR biosorbent and from $93.18 \%$ to $83.35 \%$ for PTM biosorbent. At lower initial concentrations of MB there are relatively few dye molecules and a large number of available adsorption sites, which are present in the biosorbent masses, thus, it leads to a better interaction of the adsorbate with the biosorption sites, hence resultant to the higher percentage of MB removal. With the increase in the initial concentrations of $\mathrm{MB}$ occurs the gradual decrease in the percentage of removal due to the saturation of active biosorbents sites, since with the elevation of concentration the number of the dye molecules increases significantly [55]. The increase of initial dye concentration from $10 \mathrm{mg} / \mathrm{L} \mathrm{to} 50 \mathrm{mg} / \mathrm{L}$ provided an increase in the biosorption capacity, since higher concentrations contribute to a decrease in the adsorbate mass transfer resistance of solution to the adsorbent surface, thus filling possible active sites still unoccupied in low concentrations [56,57] (Figure 4). 


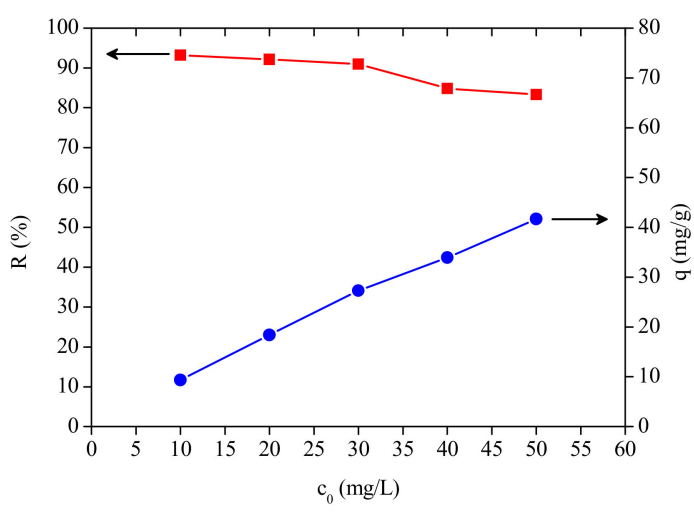

(a)

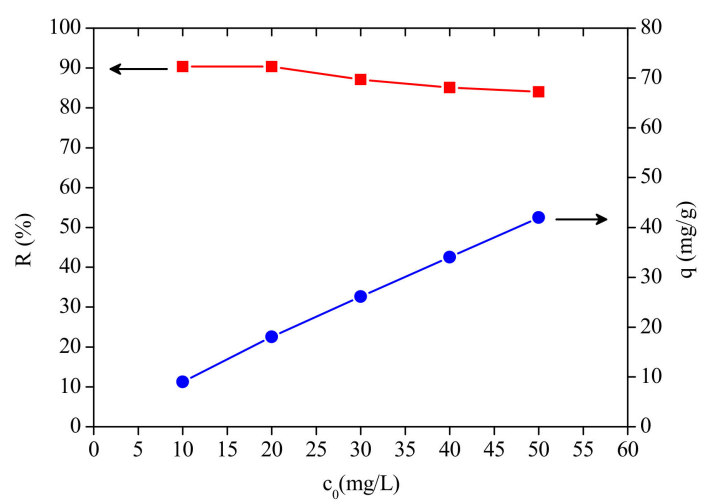

(b)

Figure 4. Initial concentration vs. percentage of removal vs. biosorption capacity: (a) PMT and (b) CCLHR.

\subsection{Adsorption Isotherms}

Isotherms are diagrams showing the variation of equilibrium concentration of adsorbent with the liquid phase concentration at a temperature. These models are used to illustrate the biosorbent interaction with the biosorbate and provide the relationship between the biosorption capacity and the liquid phase concentration of biosorbate under equilibrium condition at constant temperature [58].

\subsubsection{Langmuir Isotherm}

The Langmuir model is used in the investigation of dye biosorption from liquid solution [41]. The model based on the assumption that exists a defined number of active sites, the biosorption process occurs on a homogeneous surface through monolayer formation without any interaction with the biosorbed molecules and that all the sites has equivalent energy [56,59,60] The Langmuir isotherm [61] is represented by Equation (3).

$$
q_{e}=\frac{q_{\max } k_{L} c_{e}}{1+k_{L} c_{e}}
$$

Where:

$q_{e}=$ amount of solute adsorbed per gram of adsorbent at equilibrium $(\mathrm{mg} / \mathrm{g})$;

$q_{\text {max }}$ : maximum biosorption capacity $(\mathrm{mg} / \mathrm{g})$;

$k_{L}$ interaction constant of adsorbate/adsorbent $(\mathrm{L} / \mathrm{mg})$;

$c_{e}$ : equilibrium concentration of adsorbate $(\mathrm{mg} / \mathrm{L})$.

From Equation (3), we can obtain the linearized form:

$$
\frac{c_{e}}{q_{e}}=\frac{1}{q_{\max }} c_{e}+\frac{1}{k_{L} q_{\max }}
$$

And so, plot a chart $c_{e} / q_{e}$ in function of $c_{e}$ which allows you to calculate the which allows you to calculate the $q_{\max } \mathrm{e} k_{L}$ being that $1 / q_{\max }$ is the angular coefficient of the line and the $1 / k_{L} q_{\max }$ is the intercession with the ordinate axis.

In Langmuir's model a widely used indicator in terms of analysis is called the separation factor $R_{L}$ which is calculated on the basis of $c_{0}$ e $k_{L}$ according to Equation (5).

$$
R_{L}=\frac{1}{1+k_{L} c_{0}}
$$

$c_{0}=$ initial concentration $(\mathrm{mg} / \mathrm{L})$. 
The value of the constant $q_{\max }$ is related to the adsorbed species concentrations on the surface. When the biosorption capacity reaches this value it means that all available sites (sites that the adsorbate binds to the adsorbent) have been filled. The constant $k_{L}$ is related to the free energy of adsorption, which corresponds to the affinity between the surface of the adsorbent and the adsorbate [58]. $R_{L}$ indicates the mode of adsorbate biosorbent interaction and allows to classify adsorption isotherms in unfavorable $\left(R_{L}>1\right)$, linear $\left(R_{L}=1\right)$, favorable $\left(0<R_{L}<1\right)$, or irreversible $\left(R_{L}=0\right)$ [62].

\subsubsection{Freundlich Isotherm}

According to Freundlich model, the multilayer adsorption occurs on heterogeneous adsorbent surfaces and the higher energy sites on the surface are first occupied and the binding force decreases with the increase in the degree of occupation of the active sites, which reduces the adsorption with time [56,59].

The Freundlich model is represented by [63]:

$$
q_{e}=k_{F} c_{e}^{\frac{1}{n}}
$$

According to Cai L. et al. [44], the linearized form of Equation (6) is described by:

$$
\log q_{e}=\log k_{F}+\frac{1}{n} \log c_{e}
$$

$k_{F}$ and $n$ are the Freundlich constants related to biosorption capacity and biosorption intensity, respectively.

The adsorption isotherms obtained experimentally for PMT and CCLHR (Figure 5) were adjusted to the Langmuir and Freundlich models, for initial concentrations in the range between 10 and $50 \mathrm{mg} / \mathrm{L}$. The values of the constants were calculated by the linearized forms of the respective models. Figures 6 and 7 show Freundlich and Langmuir models for both biosorbents (PMT and CCLHR), respectively. The results for the parameters obtained in both biosorbents are shown in Table 2. Analyzing the values of the correlation coefficient in Table 2 and Figure 8, we observed that the experimental data of the adsorption for the PMT is better adjusted to the Langmuir model, while the CCLHR to the Freundlich model. It is justified by the values of the respective linear correlation coefficients ( $R^{2}$ closer to unity) in each case.

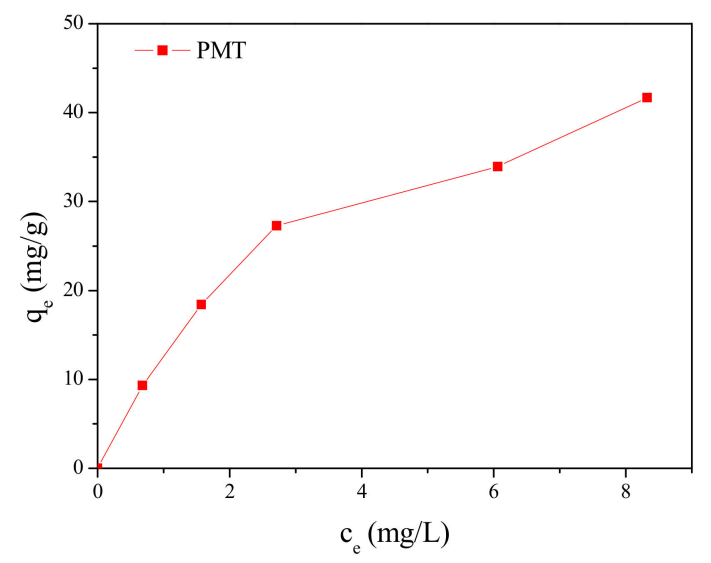

(a)

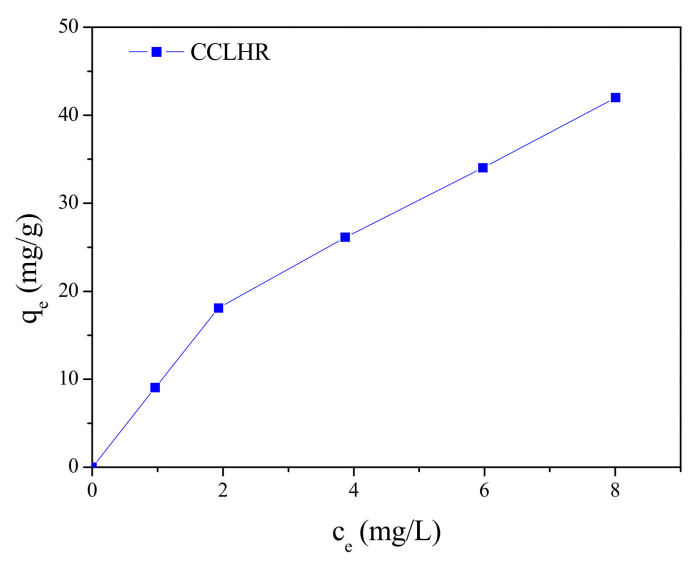

(b)

Figure 5. Adsorption isotherm of MB: (a) PMT, (b) CCLHR. 


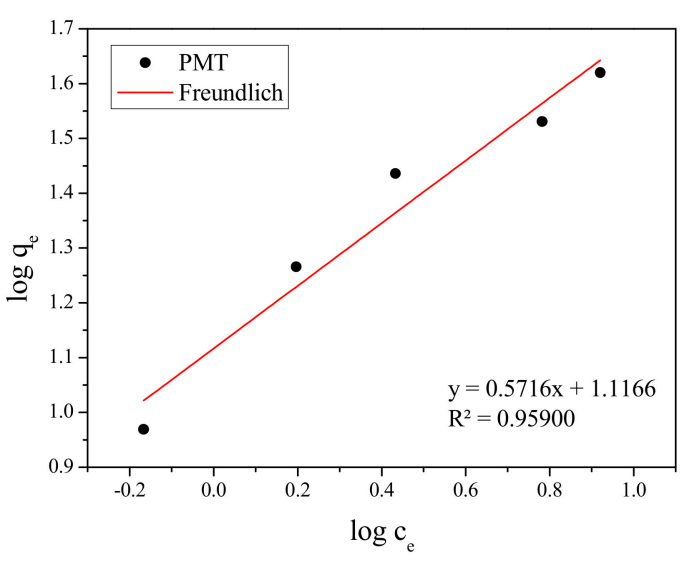

(a)

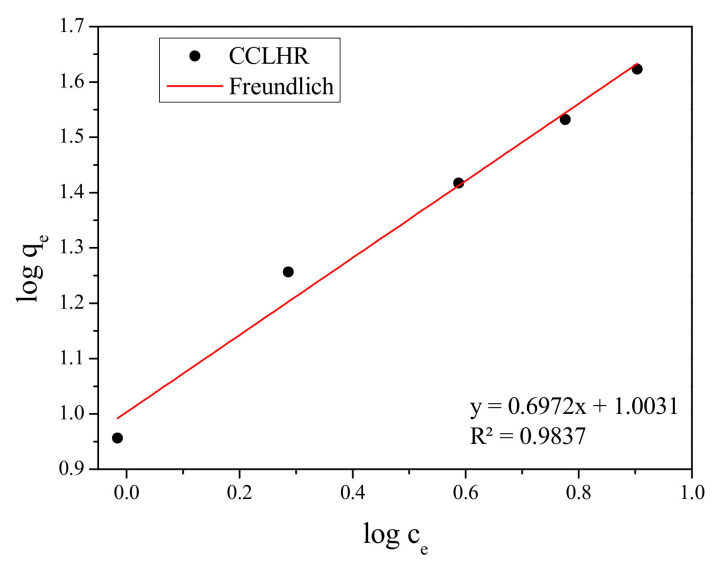

(b)

Figure 6. Freundlich isothermal adsorption equation fitting of methylene blue: (a) PMT, (b) CCLHR.

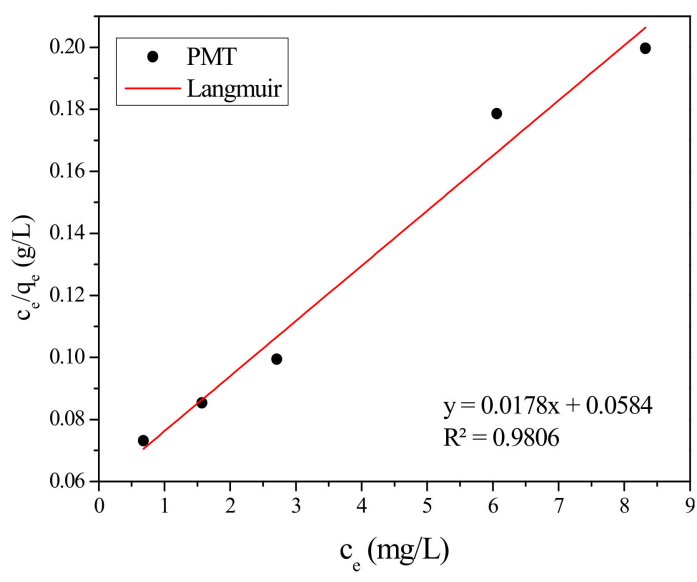

(a)

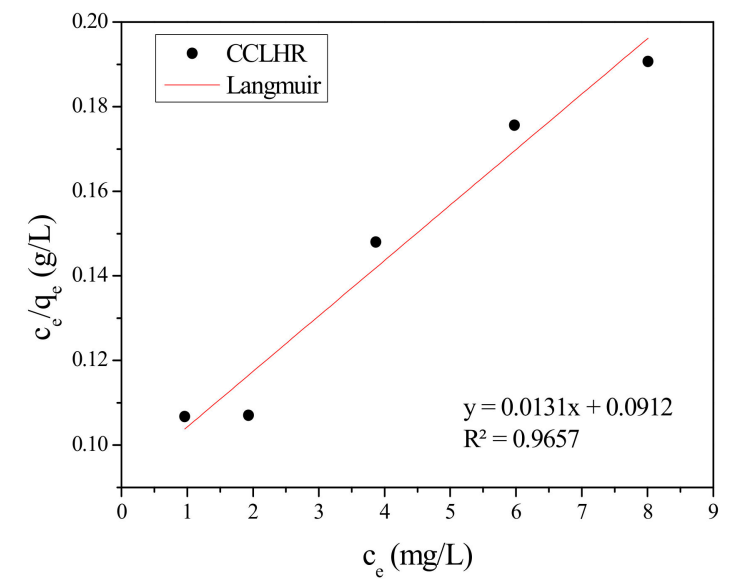

(b)

Figure 7. Langmuir isothermal adsorption equation fitting of methylene blue: (a) PMT, (b) CCLHR.

Table 2. Adsorption isotherm parameters for methylylene blue (MB).

\begin{tabular}{cccccccc}
\hline \multirow{2}{*}{ Sample } & \multicolumn{3}{c}{ Freundlich } & \multicolumn{5}{c}{ Langmuir } \\
\cline { 2 - 8 } & $\boldsymbol{n}$ & $\boldsymbol{k}_{\boldsymbol{F}}$ & $\boldsymbol{R}^{2}$ & $\boldsymbol{q}_{\text {max }}(\mathbf{m g} / \mathbf{g})$ & $\boldsymbol{k}_{\boldsymbol{L}}$ & $\boldsymbol{R}^{2}$ & $\boldsymbol{R}_{\boldsymbol{L}}$ \\
\hline PMT & 1.7495 & 13.0798 & 0.9590 & 56.1798 & 0.3048 & 0.9806 & $0.2470-0.0616$ \\
CCLHR & 1.4343 & 10.0716 & 0.9837 & 76.3359 & 0.1436 & 0.9657 & $0.4104-0.1222$ \\
\hline
\end{tabular}

In relation to the constants $k_{L}, q_{\max }$ and $1 / n$ (highest value of $n$ ) for the PMT and CCLHR Table 2 we noticed that the highest value of $k_{L}$ and lower value of $1 / n$ were found for the PMT, although the higher value of $q_{\max }$ was for CCLHR. Both models indicated higher MB affinity for PMT surface. The higher value of $q_{\max }$ for the CCLHR was possibly due to the fact of the greater diffusion in the pores and intraporos of the CCLHR than PMT. Therefore, the CCLHR presented better efficiency in relation to PMT at the conditions investigated in this work.

Various biosorbents have been applied in removal MB from the aqueous solution, as reported in the previous literature, for comparison purposes. We can compare the results with other authors in term the maximum capacity adsorbed in the conditions optimized by each authors: Carica papaya wood $\left(q_{\max }=32.25 \mathrm{mg} \cdot \mathrm{g}^{-1}\right)$ [41], Cornbread $\left(q_{\max }=106.383 \mathrm{mg} \cdot \mathrm{g}^{-1}\right)$ and pupunha palm $\left(q_{\max }=78.989 \mathrm{mg} \cdot \mathrm{g}^{-1}\right)$ [40], Potato shell $\left(q_{\max }=48.7 \mathrm{mg} \cdot \mathrm{g}^{-1}\right)$ [64], Scenedesmus $\left(q_{\max }=61.69 \mathrm{mg} \cdot \mathrm{g}^{-1}\right)$ [65]. Through the comparative study with the Table 2, we can conclude that PMT and CCLHR are between the most efficient adsorbents prepared for industrial wastewater treatment. 
The values of $R_{L}$ between 0 and 1 Langmuir model, whose variation with the initial concentration is shown in Figure 9, for both biosorbents and of $n$ between 1 and 10 Freundlich model are in Table 2, confirm that the biosorption was favorable for both the biosorbents (PMT and CCLHR), ie, the adsorbate prefers the solid phase than liquid [58].

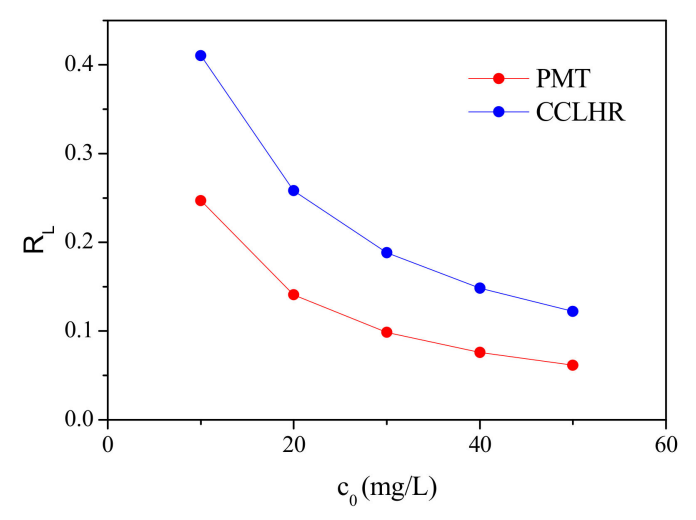

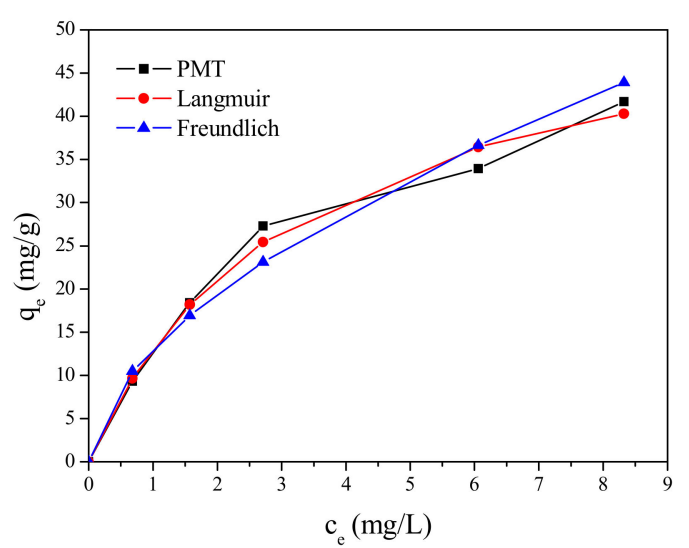

(a)

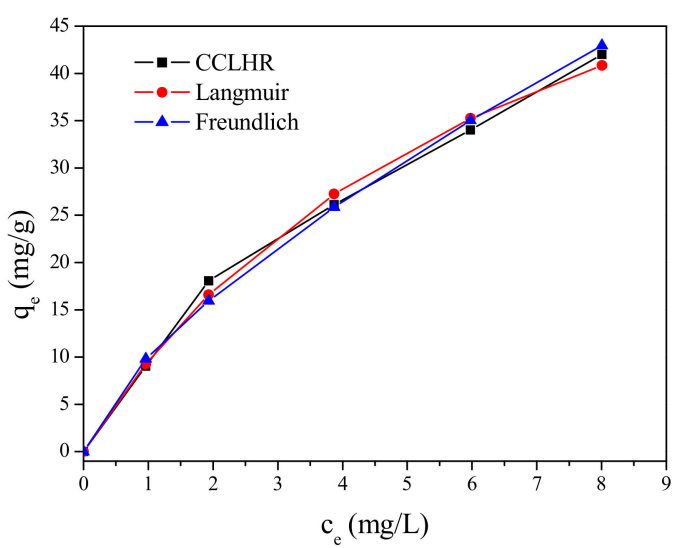

(b)

Figure 8. Adsorption isotherms with the Langmuir and Freundlich models: (a) PMT, (b) CCLHR.

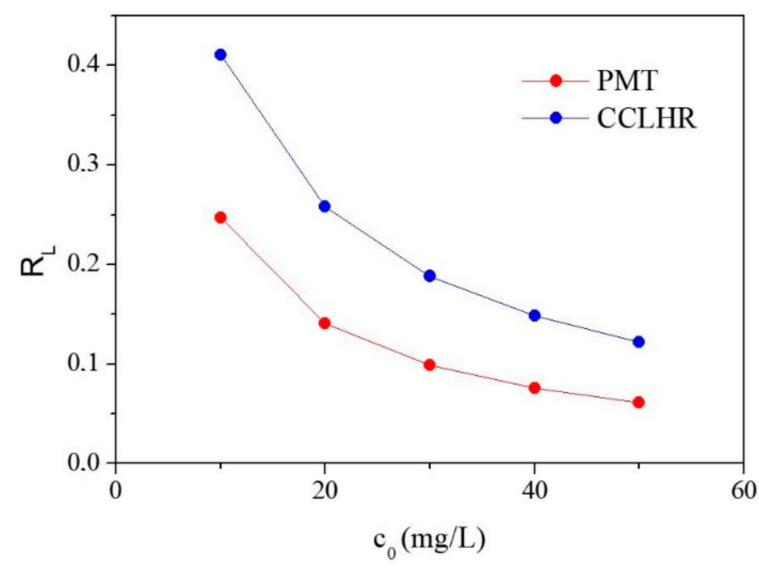

Figure 9. Curve of $R_{L}$ by the initial concentration for PMT and CCLHR.

\subsection{Adsorption Kinetics}

The biosorption with the interaction time between the biosorbents and MB was evaluated in the range of 10 to $80 \mathrm{~min}$, a concentration of $15 \mathrm{ppm}$ and a mass of $0.05 \mathrm{~g}$ was used. According to Figure 10, we observed that in the first $10 \mathrm{~min}$ occurred a rapid increase in the percentage of removal and percentage of biosorption by both biosorbents. After this period, they became slower 
and remained practically constant from $50 \mathrm{~min}$. The results are due to the fact that in the initial phase of the biosorption, the dyes particles to be biosorbed were almost entirely present in the solution with high probability of accessing the biosorbents surface and the active sites are unoccupied at the beginning of the process. With the increased of the time occurred a decrease in the concentration due to the migration of MB to unoccupied sites, which hindered the biosorption process by increasing the competition of residual dye particles for the remaining available sites. Results in terms of this behavior have already been reported in the literature [59,66-68].

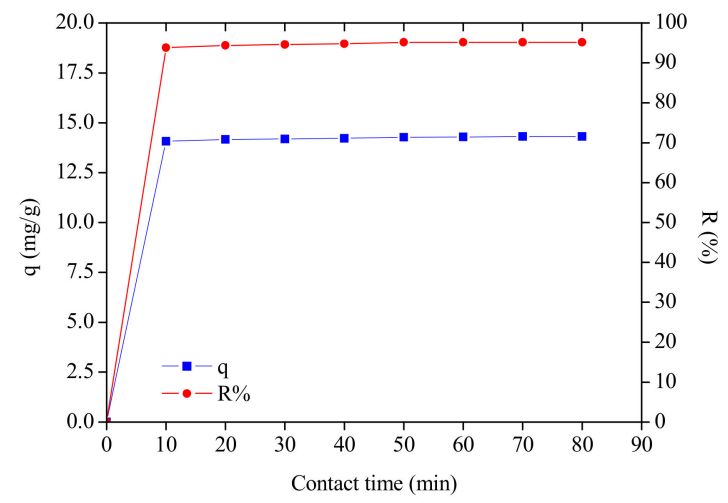

(a)

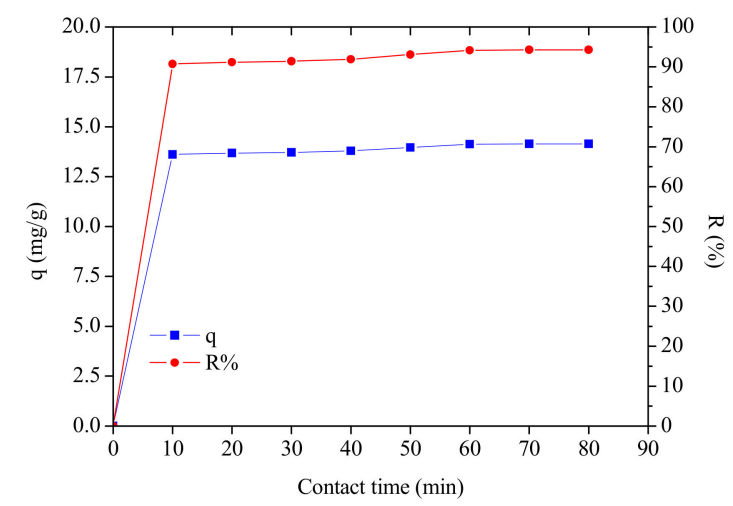

(b)

Figure 10. Contact time vs. percentage of removal vs. biosorption capacity: (a) PMT and (b) CCLHR.

In the literature, there is an expressive amount of linear kinetic models that are used to evaluate the controlling mechanism of the biosorption process such as the chemical reaction, diffusion and mass transfer [69]. Frequently, the most used models are pseudo-first-order and pseudo-second-order, which were also used in this work. The equations and their linearized forms are shown in Table 3.

Table 3. Kinetic equations of biosorption.

\begin{tabular}{ccc}
\hline Model & Equation & Linearized Formula \\
\hline Pseudo-first-order & $d q_{t} / d t=k_{1}\left(q_{e}-q_{t}\right)$ & $\ln \left(q_{e}-q_{t}\right)=\ln q_{e}-k_{1} t$ \\
Pseudo-second-order & $d q_{t} / d t=k_{2}\left(q_{e}-q_{t}\right)^{2}$ & $\frac{t}{q_{t}}=\frac{1}{k_{2} q_{e}^{2}}+\frac{t}{q_{e}}$ \\
\hline
\end{tabular}

In order to confirm the experimental data, we utilized the pseudo-first-order and pseudo-second-order models, where kinetic biosorption parameters of MB for initial concentration of $15 \mathrm{ppm}$ are shown in Table 4. In view of these results, it was observed that for both biosorbents the model that best represented the experimental data was the pseudo second order, since $\mathrm{R}^{2}$ is closer to unity. Figures 11 and 12 show the behavior of the linearized form of said models through which the parameters of Table 4 were calculated.

Table 4. Comparison of the pseudo-first-order and pseudo-second-order models for the biosorption of MB on PMT and CCLHR.

\begin{tabular}{cccc}
\hline Kinetic Model & Parameter & PMT & CCLHR \\
\hline & $\mathrm{k}_{1}(\mathrm{mg} \cdot \mathrm{min} / \mathrm{g})$ & 0.1093 & 0.1081 \\
Pseudo-first-order & $\mathrm{q}_{\mathrm{e}}(\mathrm{mg} / \mathrm{g})$ & 14.2554 & 14.1435 \\
& $\mathrm{R}^{2}$ & 0.5902 & 0.5950 \\
& $\mathrm{k}_{2}(\mathrm{mg} \cdot \mathrm{min} / \mathrm{g})$ & 0.1476 & 0.0815 \\
Pseudo-second-order & $\mathrm{q}_{\mathrm{e}}(\mathrm{mg} / \mathrm{g})$ & 14.3062 & 14.2248 \\
& $\mathrm{R}^{2}$ & 0.9998 & 0.9999 \\
\hline
\end{tabular}




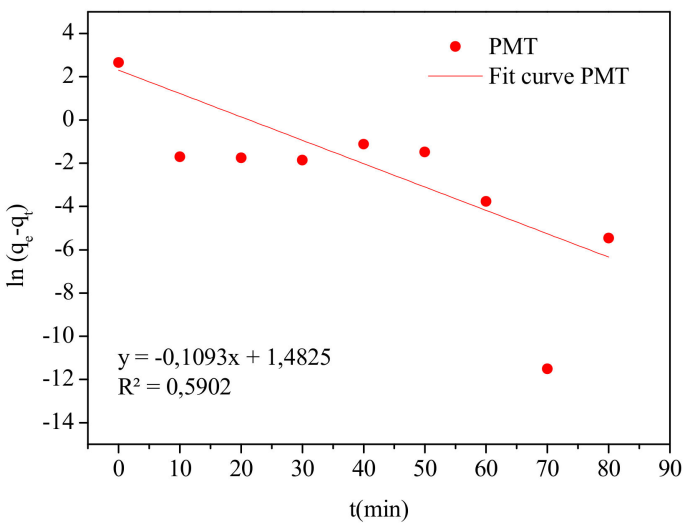

(a)

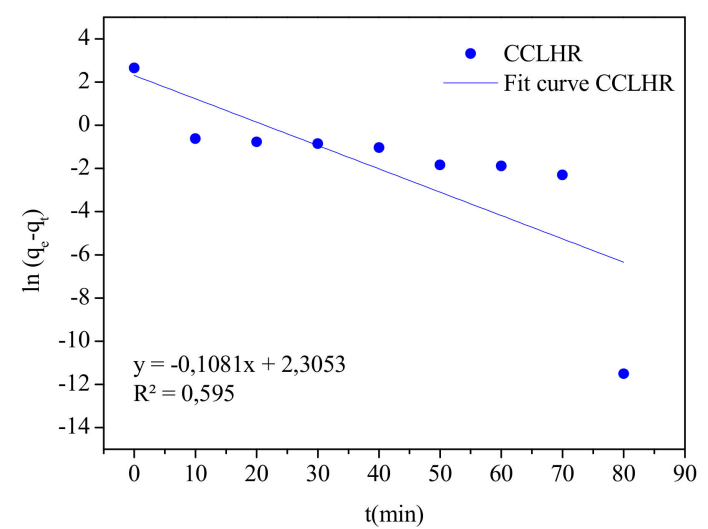

(b)

Figure 11. Plots of pseudo-first-order kinetic model for the biosorption: (a) PMT and (b) CCLHR.

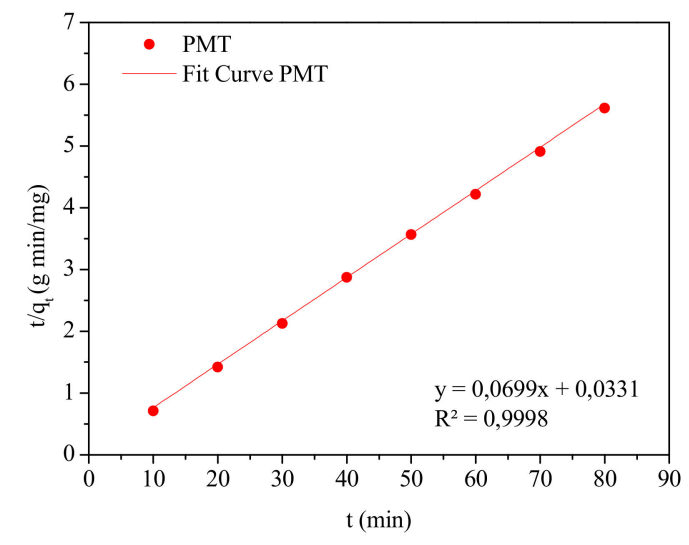

(a)

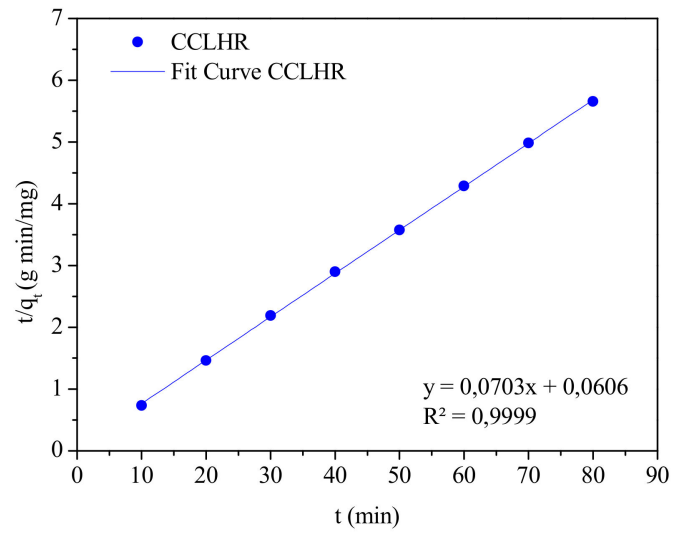

(b)

Figure 12. Plots of pseudo-second-order kinetic model for the biosorption: (a) PMT and (b) CCLHR.

\section{Conclusions}

The characterizations by FTIR and SEM showed, respectively, functional groups (hydroxyl, carbonyl and carboxyl) and high porosity surface, these factors confirm the produced biosorbents by PMT and CCLHR weeds present appropriate physical-chemical properties to adsorption process. The adsorption kinetics showed high remove percent and experimental data were most be adjusted by pseudo-second-order model. The maximum biosorption capacity $\left(q_{\max }=56.1798 \mathrm{mg} \cdot \mathrm{g}^{-1}\right.$ and $q_{\max }=76.3359 \mathrm{mg} \cdot \mathrm{g}^{-1}$ for PMT and CCLHR, respectively) showed equivalent biosorption value to literature used by $\mathrm{MB}$ removal from industries wastewater. The experimental data of the adsorption for the PMT is better adjusted to the Langmuir model, while the CCLHR to the Freundlich model. The range $R_{L}$ and $n$ results indicated favorable biosorption. Overall, the raw material showed potential for applications with low cost biosorbent, can be a viable alternative and had and with ecological appeal to remove Methylene Blue dyes by several industries segments.

\section{Patents}

In this work, the used plant raw materials are filed with the National Institute of Industrial Property (INPI)-Brazil, with the code BR 102019 008806-0. Additionally, eight weed species divided among the Cyperaceae, Poaceae, Amaranthaceae, Asteraceae families have already been tested and showed biosorption potential. 
Author Contributions: Conceptualization, F.S. and R.F.; Methodology, F.S., L.N. and M.B.; Formal analysis, R.F., W.P.J. and K.d.S.; Investigation, F.S., L.N. and M.B.; Resources, F.S. and R.F.; Writing-Original draft, F.S.; Writing—review and editing, R.F., W.P.J. and K.d.S.; Project administration, R.F. and F.S.; Supervision, R.F.

Funding: This research received no external funding.

Acknowledgments: All authors acknowledge financial support from PROPESP/UFPA, CAPES, CNPq. The authors K.S. and W.P.J. gratefully acknowledge support from Universidade Federal do Pará. The author LN gratefully acknowledge support from PIBIC/UFPA for the financial support. In addition, the authors acknowledge the use of the facilities at LABNANO-AMAZON/UFPA.

Conflicts of Interest: The authors declare no conflict of interest.

\section{References}

1. Borges, F.C.; Santos, L.S.; Correa, M.J.C. Aleopathic potential of two neolignans isolated from Virola suminanensis (Myristicaceae) leaves. Planta Daninha 2007, 25, 51-59. [CrossRef]

2. Vidotti, E.C.; Rollemberg, M.C. Algae: From economics in aquatic environments to bioremediation and analytical chemistry. Quím. Nova 2004, 27, 1-7.

3. Pereira, L.; Alves, M. Dyes-Environmental Impact and Remediation. In Environmental Protection Strategies for Sustainable Development; Strategies for Sustainability; Malik, A., Grohmann, E., Eds.; Springer: Dordrecht, The Netherlands, 2012; p. 111.

4. Tundisi, J.G.; Tundisi, T.M. Limnology, 1st ed.; Oficina de Textos: São Paulo, Brazil, 2008; p. 632.

5. Souza, N.K. Adsorption of Cationic and Anionic Dyes in Aqueous Solution Using New Bi-Functional Materials of Sugarcane Bagasse. Master's Thesis, Federal University of Ouro Preto, Ouro Preto, Brazil, 2013.

6. Ali, N.; Hameed, A.; Ahmed, S. Physicochemical characterization and bioremediation perspective of textile effluent, dyes and metals by indigenous bacteria. J. Hazard Mater. 2009, 164, 322-328. [CrossRef] [PubMed]

7. Gupta, V.K.; Suhas Ali, I.; Saini, V.K. Removal of rhodamine B, fast green, and methylene blue from wastewater using red mud, an aluminum industry waste. Ind. Eng. Chem. Res. 2004, 43, 1740-1747. [CrossRef]

8. Yamashita, M.S.J.; Kikutani, T.; Hashimoto, T. Activated carbon fibers and films derived from poly (vinylidene fluoride). Carbon 2001, 39, 207-214. [CrossRef]

9. Hu, D.D.; Lin, J.; Zhang, Q.; Lu, J.N.; Wang, X.Y.; Wang, Y.W.; Bu, F.; Ding, L.F.; Wang, L.; Wu, T. Multi-step host-guest energy transfer between inorganic chalcogenide-based semiconductor zeolite material and organic dye molecules. Chem. Mater. 2015, 27, 4099-4104. [CrossRef]

10. Shang, L.; Bian, T.; Zhang, B.; Zhang, D.; Wu, L.Z.; Tung, C.H.; Yin, Y.; Zhang, T. Graphene-supported ultrafine metal nanoparticles encapsulated by mesoporous silica: robust catalysts for oxidation and reduction reactions, Angew. Chem. Int. Ed. 2014, 53, 250-254. [CrossRef] [PubMed]

11. Hossaini, H.; Moussavi, G.; Farrokhi, M. The investigation of the LED-activated $\mathrm{FeFNS} \mathrm{TiO}_{2}$ nanocatalyst for photocatalytic degradation and mineralization of organophosphate pesticides in water. Water Res. 2014, 59, 130-144. [CrossRef] [PubMed]

12. Echavia, G.R.; Matzusawa, F.; Negishi, N. Photocatalytic degradation of organophosphate and phosphonoglycine pesticides using $\mathrm{TiO}_{2}$ immobilized on silica gel. Chemosphere 2009, 76, 595-600. [CrossRef]

13. Ahmed, S.M.; El-Dib, F.I.; El-Gendy, N.; Sayed, W.M.; El-Khodary, M. A kinetic study for the removal of anionic sulphonated dye from aqueous solution using nano-polyaniline and Baker's yeast. Arab. J. Chem. 2016, 9, S1721-S1728. [CrossRef]

14. Dabrowski, A. Adsorption e from theory to practice. Adv. Colloid Interface Sci. 2001, 93, 135-224. [CrossRef]

15. Fan, L.; Luo, C.; Sun, M.; Qiu, H.; Li, X. Synthesis of magnetic beta-cyclodextrin-chitosan/graphene oxide as nanoadsorbent and its application in dye adsorption and removal. Colloids Surf. B 2013, 103, 601-607. [CrossRef] [PubMed]

16. Guo, H.; Lin, F.; Chen, J.; Li, F.; Weng, W. Metal-organic framework MIL-125(Ti) for efficient adsorptive removal of Rhodamine B from aqueous solution. Appl. Organomet. Chem. 2015, 29, 12-19. [CrossRef]

17. Cui, Y.-Y.; Zhang, J.; Ren, L.-L.; Cheng, A.-L.; Gao, E.-Q. A functional anionic metal-organic framework for selective adsorption and separation of organic dyes. Polyhedron 2018, 161, 71-77.

18. Gupta, V.K.; Suhas. Application of low-cost adsorbents for dye removal-A review. J. Environ. Manag. 2009, 90, 2313-2342. [CrossRef] [PubMed] 
19. Gusmão, G.K.A.; Gurgel, A.L.V.; Melo, S.T.M.; Gil, L.F. Application of succinylated sugarcane bagasse as adsorbent to remove methylene blue and gentian violet from aqueous solutions-Kinetic and equilibrium studies. Dyes Pigment. 2012, 92,967-974. [CrossRef]

20. Calvete, T. Pinatura in Natura and Active Coal Shells-Adsorbents for Dye Removal in Aqueous Effluents. Ph.D. Thesis, Chemistry, Federal University of Rio Grande do Sul, Porto Alegre, Brazil, 2011.

21. Crini, G. Non-conventional low-cost adsorbents for dye removal: A review. Bioresour. Technol. 2006, 97, 1061-1085. [CrossRef]

22. Rafatullah, M.; Sulaiman, O.; Hashim, R.; Ahmad, A. Adsorption of methylene blue on low-cost adsorbents: A review. J. Hazard. Mater. 2010, 177, 70-80. [CrossRef] [PubMed]

23. Boudechiche, N.; Mokaddem, H.; Sadaoui, Z.; Trari, M. Biosorption of cationic dye from aqueous solutions onto lignocellulosic biomass (Luffa cylindrica): Characterization, equilibrium, kinetic and thermodynamic studies. Int. J. Ind. Chem. 2016, 7, 167-180. [CrossRef]

24. Kissmann, K.G. Weed and Noxious Plants, 1st ed.; BASF: São Paulo, Brazil, 1991; pp. 1-126.

25. Swetha Bindu, C.H.; Prathibha, B. Evaluation of antioxidant activity of ethanolic extrat of leaves of Cyanthilium cinereum (L). H. Rob. by using isolated frog heart. IJPPR Hum. 2018, 12, 458-465.

26. Essawy, A.A.; Ali, A.E.-H.; Abdel-Mottaleb, M.S.A. Application of novel copolymer- $\mathrm{TiO}_{2}$ membranes for some textile dyes adsorptive removal from aqueous solution and photocatalytic decolorization. J. Hazard. Mater. 2008, 157, 547-552. [CrossRef]

27. Sun, Q.Y.; Yang, L.Z. The adsorption of basic dyes from aqueous solution on modified peat-resin particle. Water Res. 2003, 37, 1535-1544. [CrossRef]

28. Gupta, V.K.; Mittal, A.; Krishnan, L.; Gajbe, V. Adsorption kinetics and column operations for the removal and recovery of malachite green from wastewater using bottom ash. Sep. Purif. Technol. 2004, 40, 87-96. [CrossRef]

29. Kunz, A.; Zamora, P.P.; Moraes, S.G.; Durán, N. New trends in effluent treatment of textile effluents. Quím. Nova 2002, 25, 78-82. [CrossRef]

30. Silva, W.L.L.D.; Oliveira, S.P.D. Modification of the adsorption characteristics of the sugarcane bagasse for the removal of methylene blue from aqueous solutions. Sci. Plena 2012, 8, 1-9.

31. Abdolali, A.; Guo, W.S.; Ngo, H.H.; Chen, S.S.; Nguyen, N.C.; Tung, K.L. Typical lignocellulosic wastes and by-products for biosorption process in water and wastewatertreatment: A critical review. Bioresour. Technol. 2014, 160, 57-66. [CrossRef]

32. Vijayaraghavan, K.; Rangabhashiyam, S.; Ashokkumar, T.; Arockiaraj, J. Assessment of samarium biosorption from aqueous solution by brown macroalga Turbinaria conoides. J. Taiwan Inst. Chem. E 2017, 74, 113-120. [CrossRef]

33. Wong, Y.C.; Senan, M.S.R.; Atiqah, N.A. Removal of methylene blue and malachite green dye using different form of coconut fibre as absorbent. J. Basic Appl. Sci. 2013, 9, 172-177. [CrossRef]

34. Mourarak, F.; Atmani, R.; Maghri, I.; Elkouali, M.; Talbi, M.; Bouamrani, M.L.; Salouhi, M.; Kenz, A. Elimination of methylene blue dye with natural adsorbent-banana peels powder. GJSFR 2014, 14, 38-44.

35. Ainane, T.; Khammour, F.; Belghazi, O.; Kabbaj, M.; Yousfi, S.; Talbi, M.M. Elkouali. Study and modelling of kinetics biosorption of methylene blue on biomass material from waste mint. Biotechnology 2015, 11, 281-285.

36. Weng, C.-H.; Lin, Y.-T.; Tzeng, T.-W. Removal of methylene blue from aqueous solution by adsorption onto pineapple leaf powder. J. Hazard. Mater. 2009, 170, 417-424. [CrossRef]

37. Senthil Kumar, P.; Abhinaya, R.V.; Gayathri Lashmi, K.; Arthi, V.; Pavithra, R.; Sathyaselvabala, V.; Sivanesan, S. Adsorption of methylene blue dye from aqueous solution by agricultural waste: Equilibrium, thermodynamics, kinetics, mechanism and process design. Colloid. J. 2011, 73, 651-661. [CrossRef]

38. Yagub, M.T.; Sen, T.K.; Ang, H.M. Equilibrium, kinetics, and thermodynamics of methylene blue adsorption by Pine tree leaves. Water Air Soil Pollut. 2012, 223, 5267-5282. [CrossRef]

39. Uddin, M.T.; Islam, M.A.; Mahmud, S.; Rukanuzzaman, M. Adsorptive removal of methylene blue by tea waste. J. Hazard. Mater. 2009, 164, 53-60. [CrossRef]

40. Honorato, A.C.; Machado, J.M.; Celante, G.; Borges, W.G.P.; Dragunski, D.C.; Caetano, J. Biosorption of methylene blue using agroindustrial residues. Rev. Bras. Eng. Agric. Amb. 2015, 19, 705-710. [CrossRef]

41. Rangabhashiyam, S.; Lata, S.; Balasubramanian, P. Biosorption characteristics of methylene blue and malachite green from simulated wastewater onto Carica papaya wood biosorbent. Surf. Interfaces 2018, 10, 197-215.

42. Carvalho, L.B. Weeds, 1st ed.; Leonardo Bianco de Carvalho: Lages, Brazil, 2013; p. 82. 
43. Pimentel, A.M.R. Removal of Co (II) and Mn (II) from Aqueous Solutions Using the Biomass R. opacus. Master's Thesis, PUC-Rio, Rio de Janeiro, Brazil, 2011.

44. Cai, L.; Zhang, Y.; Zhou, Y.; Zhang, X.; Ji, L.; Song, W.; Liu, J. Effective adsorption of diesel oil by Crab-Shell-Derived biochar nanomaterials. Materials 2019, 12, 236. [CrossRef]

45. Zhang, X.; Hao, Y.; Wang, X.; Chen, Z. Rapid removal of zinc(II) from aqueous solutions using a mesoporous activated carbon prepared from agricultural waste. Materials 2017, 10, 1002. [CrossRef]

46. Saeed, A.; Sharif, M.; Iqbal, M. Application potential of grapefruit peel as dye sorbent: Kinetics, equilibrium and mechanism of crystal violet adsorption. J. Hazard. Mater. 2010, 179, 564-572. [CrossRef]

47. Alencar, W.S.; Acayanka, E.; Lima, E.C.; Royer, B.; de Souza, F.E.; Lameira, J.; Alves, C.N. Application of Mangifera indica (mango) seeds as a biosorbent for removal of Victazol Orange 3R dye from aqueous solution and study of the biosorption mechanism. Chem. Eng. J. 2012, 209, 577-588. [CrossRef]

48. Tural, B.; Ertaş, E.; Enez, B.; Fincan, S.A.; Tural, S. Preparation and characterization of a novel magnetic biosorbent functionalized with biomass of Bacillus Subtilis: Kinetic and isotherm studies of biosorption processes in the removal of Methylene Blue. J. Environ. Chem. Eng. 2017, 5, 4795-4802. [CrossRef]

49. Royer, B.; Cardoso, N.F.; Lima, E.C.; Ruiz, V.S.O.; Macedo, T.R.; Airoldi, C. Organofunctionalized kenyaite for dye removal from aqueous solution. J. Colloid Interface Sci. 2009, 336, 398-405. [CrossRef]

50. Royer, B.; Cardoso, N.F.; Lima, E.C.; Macedo, T.R.; Airoldi, C. A useful organofunctionalized layered silicate for textile dye removal. J. Hazard. Mater. 2010, 181, 366-374. [CrossRef]

51. Da Silva, L.G.; Ruggiero, R.; Gontijo, P.M.; Pinto, R.B.; Royer, B.; Lima, E.C.; Calvete, T. Adsorption of Brilliant Red 2BE dye from water solutions by a chemically modified sugarcane bagasse lignin. Chem. Eng. J. 2011, 168, 620-628. [CrossRef]

52. Cardoso, N.F.; Pinto, R.B.; Lima, E.C.; Calvete, T.; Amavisca, C.V.; Royer, B.; Pinto, I.S. Removal of remazol black B textile dye from aqueous solution by adsorption. Desalination 2011, 269, 92-103. [CrossRef]

53. Calvete, T.; Lima, E.C.; Cardoso, N.F.; Dias, S.L.P.; Pavan, F.A. Application of carbon adsorbents prepared from the Brazilian pine-fruit-shell for the removal of Procion Red MX 3B from aqueous solution-Kinetic, equilibrium, and thermodynamic studies. Chem. Eng. J. 2009, 155, 627-636. [CrossRef]

54. Calvete, T.; Lima, E.C.; Cardoso, N.F.; Vaghetti, J.C.P.; Dias, S.L.P.; Pavan, F.A. Application of carbon adsorbents prepared from Brazilian-pine fruit shell for the removal of reactive orange 16 from aqueous solution: Kinetic, equilibrium, and thermodynamic studies. J. Environ. Manag. 2010, 91, 1695-1706. [CrossRef]

55. Hassan, W.; Farooq, U.; Ahmad, M.; Athar, M.; Khan, M.A. Potential biosorbent, Haloxylon recurvum plant stems, for the removal of methylene blue dye. Arab. J. Chem. 2017, 10, 1512-1522. [CrossRef]

56. Miraboutalebi, S.M.; Nikouzad, S.K.; Peydayesh, M.; Allahgholi, N.; Vafajoo, L.; McKay, G. Methylene blue adsorption via maize silk powder: Kinetic, equilibrium, thermodynamic studies and residual error analysis. Process Saf. Environ. Prot. 2017, 106, 191-202. [CrossRef]

57. Leal, P.V.B.; Gregório, A.M.; Otoni, E.; da Silva, P.R.; de Krauser, M.O.; Holzbach, J.C. Study of adsorption of methylene blue dye on babassu. J. Biotec. Biodiv. 2012, 3, 166-171.

58. Nascimento, R.F.; Lima, A.C.A.; Vidal, C.B.; Melo, D.Q.; Raulino, G.S.C. Adsorption: Theoretical Aspects and Environmental Applications, 1st ed.; UFC: Fortaleza, Brazil, 2014; p. 256.

59. Tang, Y.; Zeng, Y.; Hu, T.; Zhou, Q.; Peng, Y. Preparation of lignin sulfonate-based mesoporous materials for adsorbing malachite green from aqueous solution. J. Environ. Chem. Eng. 2016, 4, 2900-2910. [CrossRef]

60. Langmuir, I. The adsorption of gases on plane surfaces of glass, mica and platinum. J. Am. Chem. Soc. 1918, 40,1361-1403. [CrossRef]

61. Limousin, G.; Gaudet, J.-P.; Charlet, L.; Szenknect, S.; Barthès, V.; Krimissa, M. Sorption isotherms: A review on physical bases, modeling and measurement. Appl. Geochem. 2007, 22, 249-275. [CrossRef]

62. Pal, S.; Ghorai, S.; Das, C.; Samrat, S.; Ghosh, A.; Panda, A.B. Carboxymethyl tamarind-g-poly (acrylamide)/silica: A high performance hybrid nanocomposite for adsorption of methylene blue dye. Ind. Eng. Chem. Res. 2012, 51, 15546-15556. [CrossRef]

63. Freundlich, H.M. Over the adsorption in solution. J. Phys. Chem. 1906, 57, 385-470.

64. Alfredo, A.P.C.; Gonçalves, G.C.; Lobo, V.S.; Montanher, S.F. Adsorção de azul de metileno em casca de batata utilizando sistemas em batelada e coluna de leito fixo. Rev. Virtual Quim. 2015, 7, 1909-1920. [CrossRef] 
65. Afshariani, F.; Roosta, A. Experimental study and mathematical modeling of biosorption of methylene blue from aqueous solution in a packed bed of microalgae Scenedesmus. J. Clean. Prod. 2019, 225, 133-142. [CrossRef]

66. Kumar, A.; Jena, H.M. Removal of methylene blue and phenol onto prepared activated carbon from Fox nutshell by chemical activation in batch and fixed-bed column. J. Clean. Prod. 2016, 137, 1246-1259. [CrossRef]

67. Pang, J.; Fu, F.; Ding, Z.; Lu, J.; Li, N.; Tang, B. Adsorption behaviors of methylene blue from aqueous solution on mesoporous birnessite. J. Taiwan Inst. Chem. E 2017, 77, 168-176. [CrossRef]

68. Heidarinejad, Z.; Rahmanian, O.; Fazlzadeh, M.; Heidari, M. Enhancement of methylene blue adsorption onto activated carbon prepared from Date Press Cake by low frequency ultrasound. J. Mol. Liq. 2018, 264, 591-599. [CrossRef]

69. Da Rocha, O.R.S.; do Nascimento, G.E.; Campos, N.F.; da Silva, V.L.; Duarte, M.M.M.B. Evaluation of the adsorptive process using green coconut mesocarp for the removal of the reactive gray dye BF-2R. Quim. Nova 2012, 35, 1369-1374.

(C) 2019 by the authors. Licensee MDPI, Basel, Switzerland. This article is an open access article distributed under the terms and conditions of the Creative Commons Attribution (CC BY) license (http://creativecommons.org/licenses/by/4.0/). 